\title{
Occurrence of Ticks and Tick-Borne Diseases of Livestock in Zambezi Region: A Review
}

\author{
Percy Mashebe ${ }^{1}$, Japhet Robert Lyaku ${ }^{2} \&$ Fransisco Mausse ${ }^{3}$ \\ ${ }^{1}$ Department of Mathematics, Science and Sport Education, University of Namibia, Private Bag 1096, Winela \\ Road, Katima Mulilo, Namibia \\ ${ }^{2}$ Department of Veterinary Medicine, University of Namibia, Private Bag 13301, 340 Mandume Ndemufayo Ave, \\ Pionierspark, Windhoek, Namibia \\ ${ }^{3}$ Department of Animal Science, University of Namibia, Private Bag 13301, 340 Mandume Ndemufayo Ave, \\ Pionierspark, Windhoek, Namibia \\ Correspondence: Percy Mashebe Mashebe, Department of Mathematics, Science and Sport Education, University \\ of Namibia, Private Bag 1096, Winela Road, Katima Mulilo, Namibia. Tel: 264-66-262-6904. E-mail: \\ pmashebe@unam.na
}

\author{
Received: November 8, 2013 Accepted: December 23, 2013 Online Published: January 15, 2014 \\ doi:10.5539/jas.v6n2p142 URL: http://dx.doi.org/10.5539/jas.v6n2p142
}

\begin{abstract}
In an ecosystem such as Zambezi strip with characteristic patchwork of different land uses, land tenure types and boundaries, including country borders, veterinary fences, national parks, communal lands, government land, and forest reserves; the role played by free-ranging wildlife is a key point in the occurrence of endemic diseases such as those transmitted by tick vectors to livestock, human and wildlife hosts. Wildlife roams among different countries due to the porous nature of the borders, which makes trans-boundary management of such vector-borne diseases and natural resources a crucial issue in the southern African region. The large populations of wildlife in the tropics provide a reservoir of ticks and infective microbes that spread to domestic animals during grazing in the same environment. Ticks infesting livestock transmit numerous kinds of viruses, fungi, bacteria and protozoa between livestock, wildlife and human hosts causing poor health and socio-economic losses to their respective hosts. Since studies have indicated that there is no single, ideal solution to the control of ticks and tick-borne diseases, it becomes pertinent for stakeholders to use an integrated control, prevention and management approaches involving a comprehensive knowledge of all aspects of the vectors (ticks), hosts and aetiologic agents, particularly focusing on their biology, epidemiology and ecological issues. This review work focused on the current situation of ticks infesting livestock in Zambezi region, typical ticks of livestock, common genera of ticks infesting livestock in Zambezi region, common tick-borne diseases in Zambezi region, habitats and geographical prevalence of ticks as well as epidemiology of ticks and tick-borne diseases.
\end{abstract}

Keywords: livestock, ticks, tick-borne diseases, wildlife, Zambezi region

\section{Introduction}

Ticks belong to the invertebrate animals called phylum Arthropoda. Arthropods include crustaceans, insects, spiders, scorpions and mites. Ticks only feed as parasites (feed only on the blood of their hosts) (Walker et al., 2003). During feeding, the ticks crawl onto their host and attach to the skin with their mouthparts. When ticks have fully engorged the host's blood, they detach from the host's skin and drop to the ground. Ticks find their hosts in several ways. Some ticks live in open environments and crawl onto vegetation to wait for their hosts to pass by. This type of ambush and behaviour of waiting on vegetation is called "questing". Some adult ticks are however, active hunters and run across the ground after hosts.

The role played by free-ranging wildlife is a key point in the occurrence of endemic disease such as ticks and tick-borne diseases of livestock, mainly in an area such as the Zambezi strip with characteristic patchwork of different land uses, land tenure types and boundaries, including country borders, veterinary fences, national parks, communal lands, government land, and forest reserves (Pascucci et al., 2011). Communal lands and settlements directly bordered parks and other protected areas. Thus, wildlife, livestock and humans are in close proximity with one another, and conflict them are common, (Murphy, Mulonga, \& Suich, 2003) and this results in an increased 
risk of disease transmission at the wildlife-livestock-human interface. Belay, Yisehak, and Janssens (2012) also submitted that structural changes in the livestock sector and movement of animals, people, and pathogens between intensive and traditional production systems, which rely on different disease-control strategies, can lead to outbreak of livestock diseases.

Wildlife roams among different countries due to the porous nature of the borders, which makes trans-boundary management of such vector-borne diseases and natural resources a crucial issue in the Southern African region. In some areas however, control fences along national borders and within individual countries play a critical role in limiting the spread of diseases into domestic stocks, even though, their presence is a major and serious limiting factor to usual seasonal migrations of wildlife (Osofsky, Cumming \& Kock, 2008). The early fences were mainly directed at the control of foot and mouth disease but, as veterinary research progressed in the latter half of the twentieth century, it became apparent that numerous other diseases affecting cattle had to be considered (Morkel, 1998).

\subsection{The Study Area}

Zambezi region (Caprivi Strip) in Namibia is located on latitude $18^{\circ} 0^{\prime} 0^{\prime \prime} \mathrm{S}$ and longitude $23^{\circ} 0^{\prime} 0^{\prime \prime} \mathrm{E}$. It is in the core of Kavango-Zambezi (KAZA), Transfrontier Conservation Area (TFCA), being the largest TFCA in southern Africa embracing contiguous parts of southeast Angola, northern Botswana, northeast Namibia, southwest Zambia, and western Zimbabwe (Barnes, 2013). Figure 1 below shows the location map of Zambezi region in the KAZA Transfrontier Conservation Area. Zambezi region occupies a land area of $19,422 \mathrm{~km}^{2}$ and makes up most of the narrow strip of Namibia extending east from northern Namibia to the western tip of Zimbabwe.

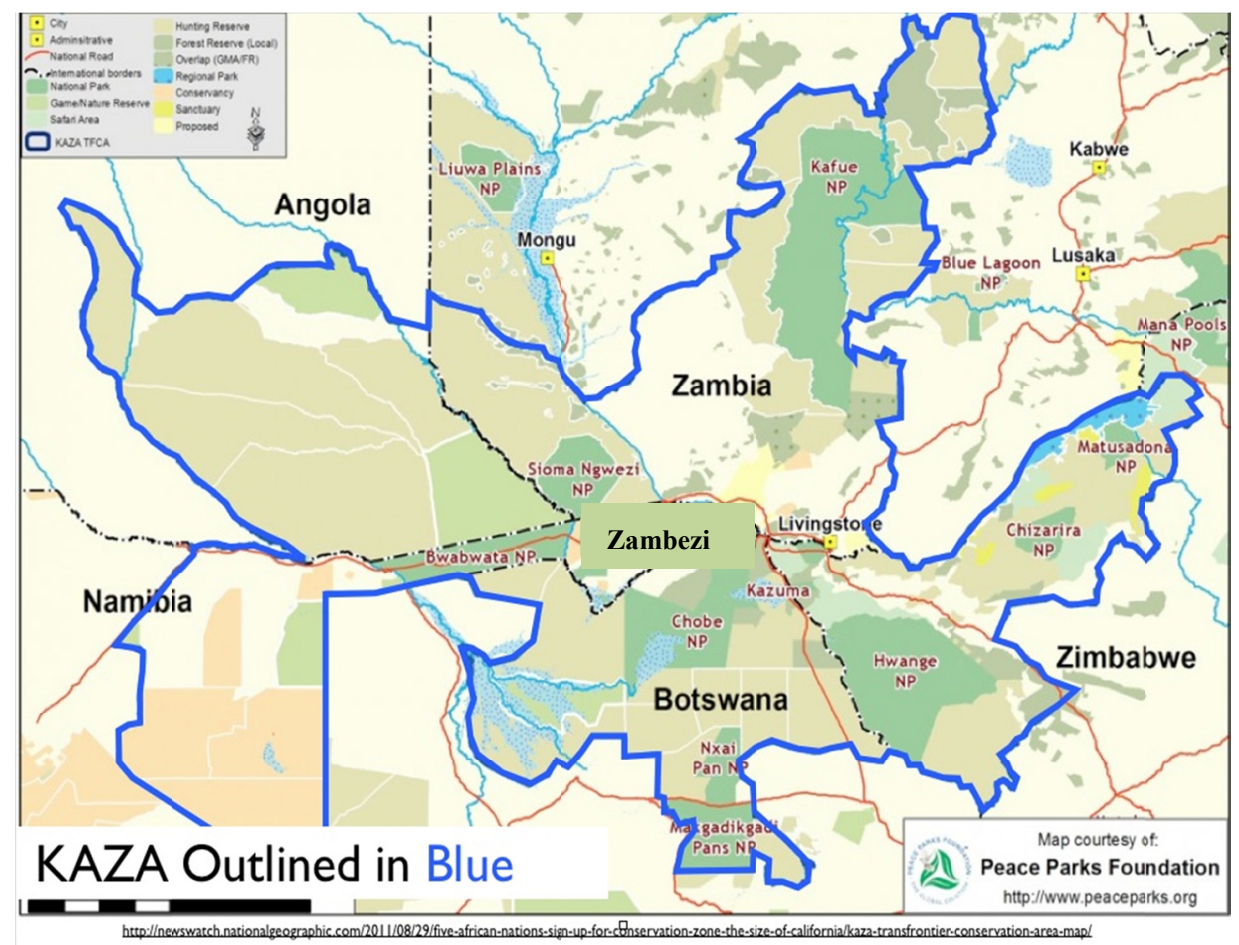

Figure 1. Map of the KAZA transfrontier conservation area showing the location of Zambezi region

Source: www.google.com.

Figure 2 below showed the location of Zambezi region on the map of Namibia. Within Namibia, the Caprivi Strip provides significant habitat for the critically endangered wild African dog and also a corridor for African elephant moving from Botswana and Namibia into Angola, Zambia and Zimbabwe. National Parks found in the Caprivi Strip are Bwabwata National Park, Mudumu National Park, and Nkasa Rupara National Park. The total human population of Zambezi was about 90,000 with majority living in the rural areas (NPC, 2012). Over 80 percent of the population in Zambezi region derived their livelihood from agriculture with livestock contributing 
to more than 70 percent of the income (New Era, 2012). Zambezi region has an estimated livestock population of 143,000 cattle, 10,000 goats, 38,000 head of poultry, and very small numbers of pigs, donkeys and sheep (Barnes, 2013). Cattle are kept by $58 \%$ of households, with only $16 \%$ of households keeping goats and $53 \%$ of households keeping some poultry (Mendelsohn, el Obeid, de Klerk, \& Vigne, 2006). Generally, Zambezi region is classified as a foot and mouth disease infected zone by the Directorate of Veterinary Services (DVS), which has the role of controlling and managing animal disease (Barnes, 2013). According to New Era (2012), Zambezi remains largely prone to outbreaks of foot-and-mouth disease due to migrating African buffaloes, believed to be carriers of the disease, a predicament that has in turn affected the marketing of livestock in the region.

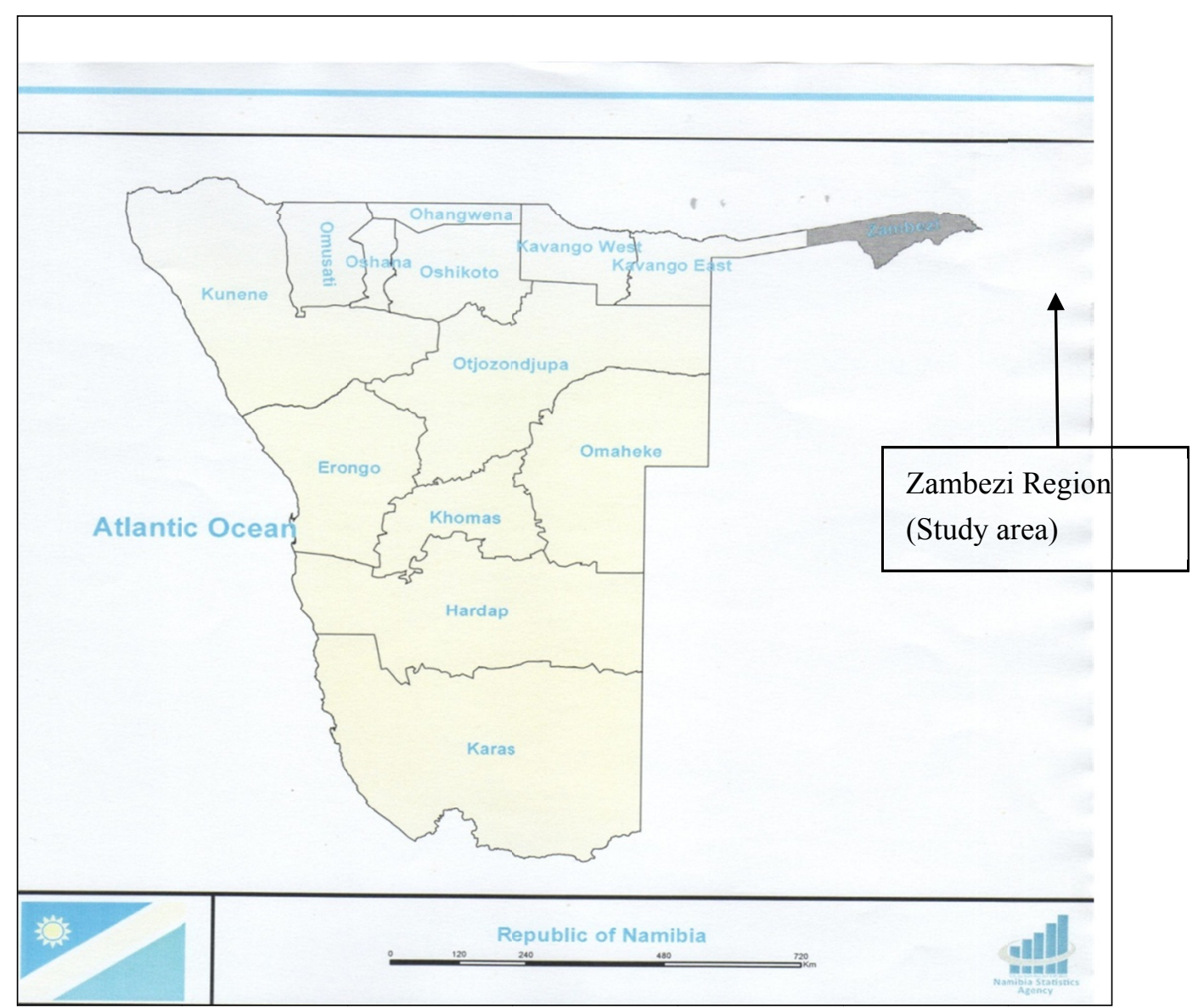

Figure 2. Map of Namibia showing the location of Zambezi Region. Source: Namibia Statistic Agency (2013)

\section{Common Genera of Ticks Infesting Livestock in Africa}

There are at least, eight hundred and sixty-six described species of tick in the world but in Africa however, 10 genera of ticks have been reported to commonly infest domestic animals; three of which are argasids while seven are ixodids (Walker et al., 2003). Argasid ticks are often called soft ticks because they do not have hard plates on their bodies while ixodids with these plates are often called hard ticks. Two genera of the argasids (Argas and Ornithodoros) only attach to their hosts for short periods; they are more commonly found within the nest or housing of their hosts. The other genus of argasid; Otobius attaches to its hosts only as larvae and nymphs and only within the ear canal.

In a Survey of ixodid ticks and two tick-borne pathogens in African Buffaloes (Syncerus caffer), in the Zambezi strip of Namibia, Pascucci et al. (2011), identified a total of two hundred and thirty-three ticks, consisting of four different species identified as Hyalomma rufipes, Amblyomma variegatum, Rhipicephalus evertsievertsi, and Hyalomma truncatum (Capobianco, Jago, Lelli, Marais, \& Scacchia, 2010). Taking vectors of tick and tick-borne diseases into account, the presence of H. rufipes, A. variegatum, R. evertsi, and H. truncatum may not exclude the occurrence of other ticks species in the region. Among the six different sampling areas covered in their study, the 
most-represented tick species was $\mathrm{H}$. rufipes while A. variegatum was found almost exclusively in Mamili National park as shown in the table below.

Table 1. Tick Species Identified by Pascucci et al (2011) and their Relative Numbers

\begin{tabular}{lllll}
\hline Capture sites & $\begin{array}{l}\text { Hyalomma } \\
\text { rufipes }\end{array}$ & $\begin{array}{l}\text { Amblyomma } \\
\text { variegatum }\end{array}$ & $\begin{array}{l}\text { Rhipicepphalusi } \\
\text { evertsi }\end{array}$ & $\begin{array}{l}\text { Hyalomma } \\
\text { truncatum }\end{array}$ \\
\hline Bwabbwatta- Mahango & 16 & 0 & 0 & 0 \\
Bwabbwatta-Buffalo & 28 & 0 & 0 & 0 \\
Bwabbwatta-West (Susuwe N and S) & 66 & 1 & 1 & 0 \\
Eastern flood plain & 0 & 2 & 5 & 0 \\
Mamili & 21 & 35 & 0 & 0 \\
Mudumu & 54 & 0 & 0 & 4 \\
Total & 185 & 38 & 6 & 4 \\
\hline
\end{tabular}

Ticks of livestock directly cause poor health and loss of production to their hosts by many parasitic mechanisms. They transmit numerous kinds of viruses, bacteria and protozoa between livestock. Ticks are particularly prevalent in tropical and subtropical countries, where the warm climate enables them to flourish. Furthermore, the large populations of wildlife in the tropics provide a large host of ticks and infective microbes that spread to domestic animals. Ticks bite can cause significant damage to livestock without any other pathogen or parasite being transmitted by the ticks. For example Amblyomma variegatum adults cause scarring on teats of cattle sufficient to reduce suckling efficiency (Walker et al., 2003). Tick-borne Diseases (TBDs) in particular, have been identified as one of the most important causes of livestock losses in Africa (Pascucci et al., 2011). It was also reported that some of these ticks constitute threat to human health but in Africa, livestock are more affected.

The risk factors for TBDs transmission between wildlife and livestock relate to the type of ecosystem or eco-zone involved; very acid savannahs and high Afro-montane eco-zones carry lower risk compared to tropical savannah such as Zambezi region where wildlife mixing is facilitated due to the presence of pastoralism inside and at the border of conservation areas (Osofsky et al., 2008). Furthermore, Norval and Horak (2004), submitted that the movements of free ranging wildlife have played very significant role in the introduction of ticks and tick-borne pathogens into new habitats as well as in maintaining a susceptible host population. Studies also indicated that the links between wildlife and livestock in some African areas are seamless; hence, knowledge and management of the disease ecology become imperative (Pascucci et al., 2011).

\section{Habitats and Geographical Prevalence of Ticks}

Generally, the prevalence of livestock diseases are attributed to environmental and climatic conditions, poor nutritional status, and poor management pattern (Duguma, Kechero, \& Janssens, 2012). Tick species are widely distributed around the world, but they tend to flourish more in countries with warm and humid climates because low temperatures inhibit their development from egg to larva (Magnarelli, 2009). For an ecosystem to support ticks, it must have high population density of host species in the area and the humidity must be high enough for ticks to remain hydrated (Wall \& David, 2001). The type of habitat in which a species of tick is found is likely to be much more widely distributed than the observed geographical range of the tick. A tick found in a similar habitat but a far away geographical area from its usual distribution may have been imported recently. Popular livestock trading routes are an important clue because ticks are carried very far on livestock in Lorries and ships (Walker et al., 2003).

Many species of ticks are adapted to seasonal variations in climate within their geographical range. In the tropics, this is usually to overcome the adverse effects of prolonged dry seasons. Dry environmental conditions are a serious danger to ticks, particularly to the questing larvae which are very susceptible to drying out fatally. The survival of many species of tick is improved if they have a seasonal cycle which reduces these risks. The survival of a population of ticks also depends on the presence of hosts suitable for reproduction by the adults (Walker et al., 2003). Studies also revealed that ticks have characteristic species of hosts to which they are adapted. For example, Rhipicephalus (Boophilus) species are adapted to feed on cattle, but some may survive by feeding on sheep or antelope. 
Ticks are adapted to two extremely contrasting components of their habitat: the physical environment and their host (Walker et al., 2003). When ticks are molting and questing in the physical environment, they are in danger of drying out, starving and freezing. They are also exposed to predators such as ants and to pathogens such as fungi. These adverse factors limit the type of habitats that a species will be found in. The needs of the same tick when feeding alter fundamentally because it is no longer in danger of drying out or starving but is in danger of being removed by the host's grooming or having its feeding reduced by host immunity (Walker et al., 2003).

\section{Common Tick-Borne Diseases (TBDs) in Zambezi Region}

The diseases associated with ticks cause much suffering to animals and huge economic loss to their owners. These continue to be a major impediment to the improvement of livestock industry in Africa, and this continent is particularly affected because of the large number of tick species and variety of diseases caused (Walker et al., 2003).

Prevalence of tick-borne diseases in Zambezi region is related to the environmental conditions with differential habitat suitability for the vectors, hosts, and their inter-relationships. Ticks and TBDs have been identified as one of the main barriers to the introduction of exotic cattle in the tropics as well as the improvement of the livestock production (Pascucci et al., 2011). Reports also indicated that there is no single, ideal solution to the control of ticks and TBDs and that the situation required an integrated control approach involving a comprehensive knowledge of the ecology of TBDs.

Cowdriosis, or heartwater, is an infectious, non contagious, tick-borne rickettsiosis caused by Ehrlichia ruminantium and affects both domestic and wild ruminants. This disease is widespread across Africa, where in combination with East Coast fever and trypanosomosis, is responsible for the heaviest losses to livestock (Allsopp et al., 2004). Wild ruminants are the main reservoir of cowdriosis and are asymptomatic carriers; domestic ruminants, especially imported breeds are particularly susceptible to this disease, which is one of the major obstacles to genetic selection in sub-saharan countries (Allsopp, Bezuidenhout, \& Prozesky, 2004). Twelve African ruminants have been demonstrated to be infected with E. ruminantium (Pascucci \& Pressi, 2007). Wild animals are normally included in the host range of E. ruminantium vectors (Amblyomma ticks), and among them, the African buffalo, (Syncerus caffer) is one of the most important capable of feeding a large number of ticks (Gallivan \& Horax, 1997) with extended effects, particularly in cattle. African buffaloes are large bovid that prefer savannah-type habitats and most woodland types in the southern African region provide a suitable habitat. A large number of these animals moved through the Zambezi strip into neighboring countries. Generally, any area that is capable of supporting cattle would also support buffalo. Thus, there is high potential for the transfer of contagious tick-borne diseases among these species of animals.

Theileria parva is transmitted mainly by ticks that belong to the Rhipicephalus appendiculatus group, and it is responsible for causing East Coast fever, a fatal disease of cattle. The African buffaloes have been reported as the wildlife reservoir of the T. parva buffalo strain, which causes corridor disease in cattle (Latif, Hove, Kanhai, \& Masaka, 2002). The parasite probably originated from African buffalo populations in eastern Africa and became adapted to cattle after their introduction and dissemination into the region, especially in the Lake Victoria Basin and along the Zambezi strip. Presently, after the extensive eradication campaign of the $T$. parva, the cattle-associated strain; the major parasite pool is maintained by buffalo, and when ticks from buffalo feed on cattle, the cattle are likely to become infected with the $T$. parva buffalo-strain and develop corridor disease (Grootenhuis, 1989). African buffaloes may be infested with exceptionally large numbers and various species of ixodid ticks (Horak, De Vos, \& Brown, 1983).

The incidence of biting stress is another worrisome dimension of tick-borne disease of livestock to farmers in the Zambezi region. When a hard tick pierces the skin of its host, initially little or no pain is caused. However, prolonged feeding by the ticks caused inflammation at the wound. Infestations of ticks on domestic and wild animals can build up to very high levels. On a herd basis, the accumulated effect of this biting stress can cause loss of appetite (anorexia) and loss of blood. These result in reduced food intake and anemia with lowering effect on growth rate and milk production (Jonsson, 2006; Pegram, 1991). The feeding of soft ticks can cause severe biting stress because of the pain whilst they feed; Ornithodoros savignyi is one notorious example.

Larger ticks such as Amblyomma variegatum adults which often feed on udders of cattle cause obstructive and painful damage, and reduce suckling by the calves. Hyalomma truncatum adults feed on the feet of sheep and goats causing lameness. Wounds caused by dense clusters of adult ticks can make the host susceptible to infestation with larvae of flesh-eating myiasis flies, such as the screw-worm (Jonsson, 2006; Stachurski, 2000). At each feeding site of hard ticks, granuloma and wound healing produce a scar that remains for years after the tick has detached. 
When the skin of livestock animals is made into leather these scars remain as blemishes that reduce the value of the leather.

A moist eczema, sometimes with hair loss (= alopecia) known as sweating sickness in cattle (Figure 3) is caused by Hyalomma truncatum and this paralysis can be life threatening (Stone, 1989). Because ticks feed repeatedly and only on blood, and have long lives, they are suitable hosts for many types of microbe. The microbes exploit the ticks for transmission between one domestic animal and another. Amblyomma variegatum adult ticks which feed on cattle cause a systemic suppression of immunity in the host making dermatophilosis to become severe or even fatal (Martinez, 1993).

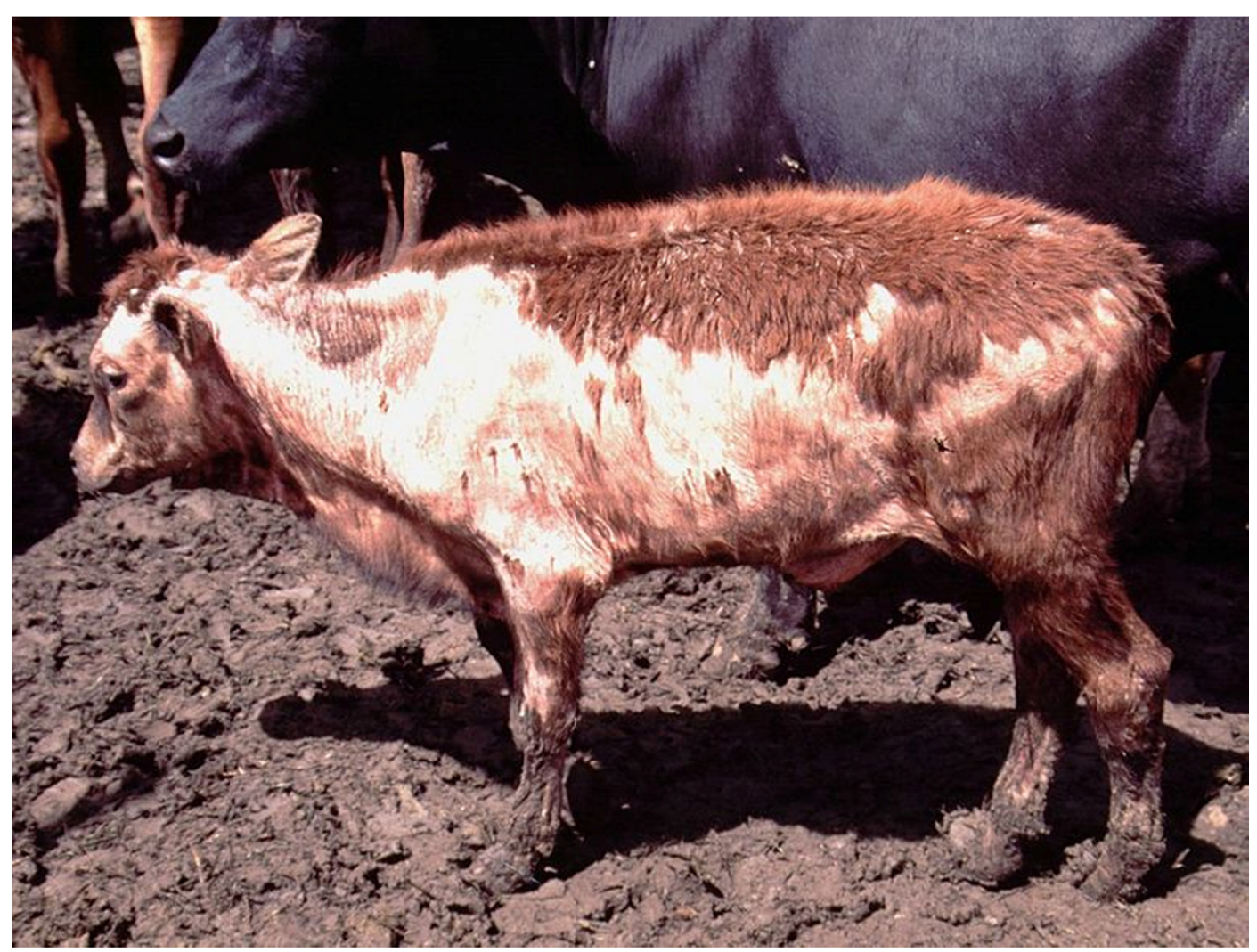

Figure 3. Calf showing signs of sweating sickness

\section{Epidemiology of Tick and Tick-borne Diseases}

Tick and tick-borne diseases are classified as an endemic disease of livestock (Maropofela \& Oladele, 2012). Generally, the prevalence wildlife based tourism has been identified as key for regional and national development in Namibia but the management of wildlife and livestock diseases across protected areas (including envisaged trans-boundary conservation areas and neighbouring lands) remains unresolved and is an issue of major concern for both conservation and economic development (David, 2005). Tick-borne diseases are a constraint to livestock production in many developing countries as they cause high morbidity and mortality, which results in decreased production of meat, milk and other livestock by-products. A characteristic of diseases caused by tick transmitted microbes is the epidemiological state of endemic stability that commonly develops in herds or flocks of livestock. The most important tick-borne diseases of livestock in sub-Saharan Africa are East Coast fever (caused by Theileria parva), babesiosis (caused by Babesia bigemina and B. bovis), anaplasmosis (caused by Anaplasma marginale) and heartwater (caused by Ehrlichia ruminantium) (Simuunza, Weir, Courcier, Tait, \& Shiels, 2011). The maintenance of extensive livestock systems and to some extent, the close association between wildlife and livestock has been identified as the main reason for the current disease status. The concerns over wildlife as a source of infection were sometimes justified as efforts to establish commercial livestock industries were frequently failing or constrained as a result of disease outbreaks, some of which could be attributed to contact with wildlife.

The use of new, highly sensitive diagnostic methods has revealed persistent infections to be a common feature of different tick-borne diseases. Studies have indicated that Antigenic variation can contribute to disease persistence 
through the continual elaboration of new surface structures (Barbet, 2009). Many facets of wildlife/livestock interface, such as health, conservation, environment, culture, and economics, have been issues since livestock became an integral part of Zambezi landscape. Given the increasing economic benefits from wildlife, health issues are an increasing concern in this field especially where epidemics and chronic disease problems occur as a result of introduced disease. One basic problem in Africa is the lack of sufficient basic field data on the interactions at the wildlife/livestock/environment interface in relation to disease. Generally, the epidemiology of ticks and tick-borne diseases is changing, especially because of changes in the environmental characteristics, including both farm and herd management conditions and climatic conditions. Under favorable breeding conditions, these modifications can provoke an increase in the tick stocks, an increase in the contact rate between livestock and ticks, and an increase in the contact rate between livestock and the wildlife.

\section{Conclusion}

A number of diseases of socio-economic importance are shared between livestock and wildlife. Disease can adversely affect animal population dynamics in the short and long term and increases the risk of the extinction of rare species. The more subtle effects of disease are to make a livestock and wildlife population more susceptible to other impacts, such as predation. Recent research works indicated that there are persistent livestock infections with common features of different tick-borne diseases. Tick-borne diseases are a major constraint to livestock production in Zambezi region of Namibia and indeed, many developing countries. Currently, there is no single, ideal solution to the control of ticks and tick-borne diseases. Thus, it becomes pertinent for stakeholders to use an integrated control approach involving a comprehensive knowledge of the ecology of tick-borne diseases.

\section{References}

Allsopp, B. A., Bezuidenhout, J. D., \& Prozesky, L. (2004). Heart water. In J. A. W. Coetzer, \& R. C. Tustin (Eds.), Infectious Disease of Livestock (2nd ed., pp. 507-535). Oxford, United Kingdom: Oxford Univ. Press.

Barbet, A. F. (2009). Persistence mechanisms in tick-borne diseases. Onderstepoort J. Vet. Res., 76(1), 53-8. http://dx.doi.org/10.4102/ojvr.v76i1.65

Barnes, J. I. (2013). Economic Analysis of Land Use Policies for Livestock, Wildlife and Disease Management in Caprivi, Namibia, with Potential Wider Implications for Regional Transfrontier Conservation Areas. Technical Report to the Wildlife Conservation Society's AHEAD Program and the World Wildlife Fund.

Belay, D., Yisehak, K., \& Janssens, G. P. J. (2012). Socio-economic factors influencing urban small-scale diary management practices in Jimma town, Ethiopia Libyan. Agri. Res. Center J. Int., 3, 1-6.

Capobianco, D. A., Jago, M., Lelli, R., Marais, A., \& Scacchia, M. (2010). Preliminary report oftransfrontier disease surveillance in free-ranging buffalo in the Caprivi Strip, Namibia. Vet. Ital., 46, 267-275.

David, C. (2005). Animal health for the environment and development (AHEAD): possibleapplications in Namibia? AHEAD Workshop Proceedings: 29 November 2005.

Duguma, B., Kechero, Y., \& Janssens, G. P. J. (2012). Survey of major diseases affecting dairy cattle in jimma town, oromia, Ethiopia. Global veterinaria, 8, 62-66.

Gallivan, G. J., \& Horak, I. G. (1997). Body size and habitat as determinants of tick infestations of wild ungulates in South Africa. South African Journal of Wildlife Research, 27, 63-70.

Grootenhuis, J. (1989). The role of wildlife in the epidemiology of cattle theileriosis in THEILERIOSIS in Eastern, Central and Southern Africa. Proceedings of a workshop on East Coast fever immunization held in Lilongwe, Malawi 20-22 September 1988.

Horak, I. G. (1987). Arthropod parasites of some wild animals in South Africa and Namibia. Onderstepoort J. Vet. Res., 58, 207-211.

Horak, I. G., De Vos, V., \& Brown, M. R. (1983). Parasites of domestic and wild animals in South Africa. XVI. Helminth and arthropod parasites of blue and black wildebeest (Connochaetes taurinus and Connochaetes gnou). Onderstepoort J. Vet. Res., 50, 243-255.

Jonsson, N. N. (2006). The productivity effects of cattle tick (Boophilus microplus) infestation on cattle, with particular reference to Bos indicus cattle and their crosses. Veterinary Parasitology, 137(1-2), 1-10. http:dx.doi.org/10.1016/j.vetpar.2006.01.010

Latif, A., Hove, T., Kanhai, G., \& Masaka, S. (2002). Buffalo-associated Theileria parva: the risk to cattle of buffalo translocation into the Highveld of Zimbabwe. Ann. N. YAcad Sci., 969, 275-279. http://dx.doi.org/10.1111/j.1749-6632.2002.tb04392.x 
Magnarelli, L. A. (2009). Global importance of ticks and associated infectious disease agents. Clinical Microbiology Newsletter, 31(5), 33-37. http://dx.doi.org/10.1016/j.clinmicnews.2009.02.001

Maropofela, K., \& Oladele, O. I. (2012). Farmers competencies on identification of lumpy skin disease symptoms and management practices in Mafikeng municipality of north-west province, South Africa. J. Anim. Veterin. $A d v$., 11, 3493-3498. http://dx.doi.org/10.3923/javaa.2012.3493.3498

Martinez, D. (1993). Epidemiological studies of dermatophilosis in the Caribbean. Revue d'Elevage et de Medicine Veterinaire des Pays Tropicaux, 10, 323-327.

Mendelsohn, J., el Obeid, S., de Klerk, N., \& Vigne, P. (2006). Farming systems in Namibia. Namibia National Farmers Union (NNFU), Windhoek, Namibia.

Morkel, P. (1998). Introduction of disease-free African buffalo (Syncerus caffer) to game farms in Namibia. Republic of Namibia, Ministry of Environment and Tourism. Windhoek, Namibia.

Murphy, C., Mulonga, S., \& Suich, H. (2003). DEA Research Discussion Paper Number 59: The Conflict Continues: Human Wildlife Conflict and Livelihoods in Caprivi. Retrieved October, 4, 2013, from http://www.dea.met.gov.na

New Era (2012). Boost for cattle marketing in Caprivi. Retrieved May, 10, 2013, from http://allafrica.com/stories/201306050908.html

Norval, R. A. I., \& Horak, I. G. (2004). Ticks. In J. Coetzer, \& R. R. Tustin (Eds.), Infectious Disease of Livestock (2nd ed., pp. 3-42). Oxford, United Kingdom: Oxford Univ. Press.

NPC. (2012). Namibia 2011 population and housing census preliminary results. National Planning Commission, Windhoek, Namibia.

Osofsky, S. A., Cumming, D. H. M., \& Kock, M. D. (2008). Transboundary management of natural resources and the importance of a 'one health' approach: Perspectives on Southern Africa. In E. Fearn, \& K. H. Redford (Eds.) State of the Wild 2008-2009: A Global Portrait of Wildlife, Wild lands, and Oceans (pp. 89-98). Washington, DC.: Island Press

Pascucci, I., \& Pressi, G. (2007). Heartwater. Idropericardite infettiva dei ruminanti. Vet.Ital., 1-90.

Pascucci, I., Dondona, A. C., Camma, C., Marcacci, M., Di Domenico, M., Lelli, R., ... Caporale, V. (2011). Survey of ixodid ticks and two tick-borne pathogens in African Buffaloes,Synceruscaffer, from the Caprivi strip, Namibia. Journal of Zoo and Wildlife Medicine, 42(4), 634-640. http://dx.doi.org/10.1638/2011-0014.1

Pegram, R. G. (1991). Studies on the economics of ticks in Zambi, Exp. Appl. Acarol., 12, 9-26. http://dx.doi.org/10.1007/BF01204396

Simuunza, M., Weir, W., Courcier, E., Tait, A., \& Shiels B. (2011). Epidemiological analysis of tick-borne diseases in Zambia. Vet parasitol., 175(3-4), 331-42. http://dx.doi.org/10.1016/j.vetpar.2010.09.027

Stachurski, F. (2000). Invasion of West African cattle by the tick Amblyomma variegatum. Medical and Veterinary Entomology, 14(4), 391-399. http://dx.doi.org/10.1046/j.1365-2915.2000.00246.x

Stone, B. F. (1989). Tick/host interactions for Ixodes holocyclus: role, effects, biosynthesis and nature of its allergenic oral secretions. Exp. Appl. Acarol., 7, 59-69. http://dx.doi.org/10.1007/BF01200453

Walker, A. R., Bouattour, A., Camicas, J. L., Estrada-Peña, A., Horak, I. G., Latif, A. A., ... Preston, P. M. (2003). Ticks of domestic animals in Africa: a guide to identification of species. Bioscience reports (pp. 1-56), Edinburgh Scotland, U.K..

Wall, R., \& Shearer, D. (2008). Veterinary ectoparasites: biology, pathology and control (pp. 55-82).

\section{Copyrights}

Copyright for this article is retained by the author(s), with first publication rights granted to the journal.

This is an open-access article distributed under the terms and conditions of the Creative Commons Attribution license (http://creativecommons.org/licenses/by/3.0/). 